\title{
New Perspectives of the Environmental Analysis and Ecology Studies
}

\begin{abstract}
Katerina Kabassi*
Department of Environmental Technology, Technological Educational Institute of the Ionian Islands, Greece

*Corresponding author: Katerina Kabassi, Department of Environmental Technology, Technological Educational Institute of the Ionian Islands, Greece
\end{abstract}

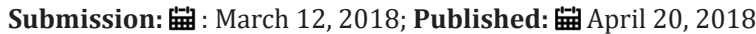

\section{Editorial}

Research on Environmental Analysis and Ecology provides academia with important papers significant technologies or case studies in the environment. A new interesting perspective that would be of interest to a wide readership is the use of Information and Communications Technologies in Environmental Analysis and Ecology. This may involve research and developments in the application of Information and Communication Technologies to the environment. Interesting topics on this subject involve: Environmental Software, Multi-Criteria Decision Making Analysis of environmental or ecological problems, Environmental Databases, Geographical Information Systems, Remote Sensing, etc. For this purpose, different review papers have been published. An interesting survey on environmental informatics in Europe until 2006 was presented by Pillman et al. [1]. Another interesting review is presented by Athanasiadis [2] who summarized the developments in environmental informatics that exploited agent technology. The synergies between environmental informatics and Knowledge Management are explored by Tochtermann \& Maurer [3].

An important field, in which different research papers have been published to exploit new techniques, is that of waste management. For example, Zeng \& Trauth [4] have developed Web-based Fuzzy Multicriteria Decision Support System for solid waste management. In some cases different research areas have been combined in the field of Environmental Analysis. For example Monprapussorn et al. [5] combine Geographic Information Systems with Multi Criteria Decision Analysis for the selection of route for transporting hazardous waste. New Technologies have also been used for warning and protecting people for physical disasters. For example, Wang \& Du [6] have developed a Web-based System for warning users against floods. In view of the above, one can easily notice how the Information and Communication Technologies have influenced and changed the subject of Environmental Analysis and Ecology.

\section{References}

1. Pillmann W, Geiger W, Voigt K (2006) Survey of environmental informatics in Europe. Environmental Modelling \& Software 21(11): 1519-1527.

2. Athanasiadis IN (2005) A review of agent-based systems applied in environmental informatics. In: Zerger A, Argent RM (Eds.), MODSIM 2005 Intl Congress on modelling and simulation. Modelling and Simulation Society of Australia and New Zealand, pp. 1574-1580.

3. Tochtermann K, Maurer H (2000) Knowledge management and environmental informatics. Journal of Universal Computer Science 6(5): 517-536.

4. Zeng Y, Trauth KM (2005) Internet-based fuzzy multicriteria decision support system for planning integrated solid waste management. Journal of Environmental Informatics 6(1): 1-15.

5. Monprapussorn S, Thaitakoo D, Banomyong R, Watts DJ (2007) The application of geographic information system and multi criteria decision analysis: toward hazardous waste transport sustainability. Environmental Informatics Archives 5: 480-487.

6. Wang $\mathrm{XH}, \mathrm{Du} \mathrm{CM}$ (2003) An internet based flood warning system. Journal of Environmental Informatics 2(1): 48-56.
Creative Commons Attribution 4.0 International License

For possible submissions Click Here

\section{Submit Article}

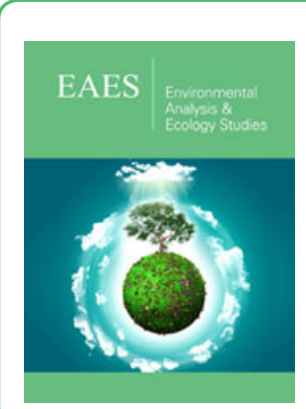

Environmental Analysis \& Ecology Studies

\section{Benefits of Publishing with us}

- High-level peer review and editorial services

- Freely accessible online immediately upon publication

- Authors retain the copyright to their work

- Licensing it under a Creative Commons license

- Visibility through different online platforms 